\title{
Forum
}

\section{Ancient Herstories}

\section{Maria Haley and Elinor Cosgrave}

Ancient Herstories aims to tell the stories of women from the ancient world: the good, the bad and the ugly. It is a blog developed by Maria Haley and Elinor Cosgrave, who became frustrated at the male-centred history modules they had encountered while teaching.

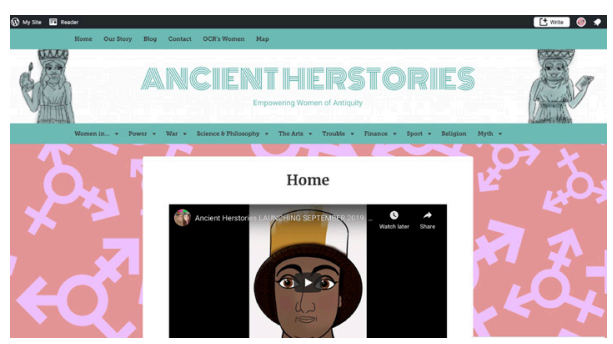

https://ancientherstories.com

Drawing on Elinor's expertise in Roman captive women and gender in antiquity, along with Maria's background working in schools with Classics for All, the pair teamed up to tell these stories to a young audience (age 13+). Ultimately, it is intended that the project will be edited and published as an illustrated non-fiction book for young adults.

The aims of the project were clear: to put the ancient women in context, to evaluate their actions and the evidence for them, and to make the stories relevant to a modern audience. With this in mind the website includes tabs on context, including time and place. Although the website is ordered thematically, it contains links to make cross references to allow for comparisons and context. Elinor strives only to include open-access secondary material and translations of primary sources, so that interested readers can follow the links to learn more. Maria bases her illustrations of the women on artefacts, art and pop-culture posters that convey the story. For example, you might spot Kill Bill, or an album cover of Destiny's Child amidst illustrations based on Waterhouse paintings and archaeological evidence. Making ancient women seem relevant to a modern audience is at the heart of the project and contemporary references can help signpost some of the challenges presented in the stories of poisoners, rape survivors and feuding families.

Author of correspondence: Maria Haley, E-mail: maria.l.haley@gmail.com

Cite this article: Haley M and Cosgrave E (2020). Ancient Herstories. The Journal of Classics Teaching 21, 95-96. https://doi.org/10.1017/S2058631020000525

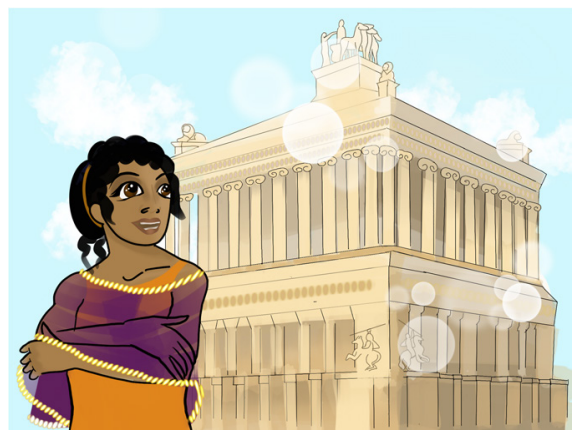

Rejected Princesses: https://www.rejectedprincesses.com/

This approach has led to criticism from some online audiences. The most troubling complaints have centred on the depiction of race. When an illustration of Artemisia of Caria - the only woman to have built an Ancient Wonder of the World, the Mausoleum of Halicarnassus - was published online, some objected to the depiction of this Persian woman as 'too black', 'sub-Saharan or worse'. Fortunately, online platforms allow hate-speech to be reported, which the project leads did, as many critiquing the project are not interested in engaging in meaningful debate or providing helpful feedback. These illustrations are based on evidence such as the bust of Atossa, which depicts almond eyes and curled hair but no colouring. Given that evidence on ethnicity in the ancient world is problematic, Maria made the creative decision to treat white faces as an option, not a default, and to illustrate Persian women as middle-Eastern with dark hair, dark eyes and dark skin.

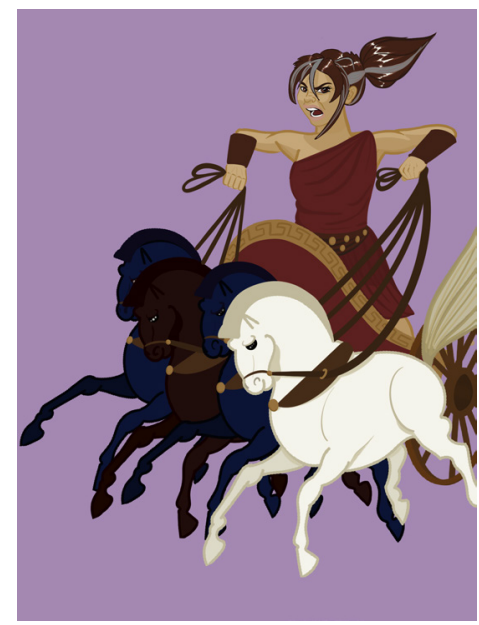

Tough Mothers: https://www.rejectedprincesses.com/book2 
The women are selected for inclusion in the project either by suggestions from the online community, or from a list of key figures from the authors' teaching or research. Some of the women feature on the Women in the Ancient World module for GCSE Classical Civilisation, which only $18 \%$ of schools which teach Classical Civilisation take up. Readers therefore can now expect the next few women to be taken from the stories of Early Rome, as Maria has just designed a package of GCSE Ancient History lessons from the Early Rome period study. Women with positive stories are not cherry-picked, nor are the villainous women sanitised, but each story is adapted and presented with a bullet-point list of key issues with the evidence. The truth, then, does not get in the way of a good story, but enhances it as young readers are encouraged to be curious and equipped to follow the links and learn even more.

Inspired by 'Rejected Princesses' and 'Tough Mothers', which present figures from global history, Ancient Herstories aims to draw together women's stories from the classical period so that they can be viewed in context and can spark curiosity about evidence from antiquity. For too long, the lack of evidence from female writers has curbed the study of women in the ancient world on Classical curricula, and Ancient Herstories aims to make research on these figures accessible and interesting to young readers. In 2021 Ancient Herstories will complete four figures per theme and approach a publisher to produce a hardback gift edition. 